\title{
Internationalization of Bulgarian Clusters
}

\begin{abstract}
A number of studies ascertain the role clusters play in increasing the competitive power, innovations and economic development of separate countries. The internationalization of clusters is among the factors which contribute to their future development. Small and medium enterprises, which operate on an international level as part of a cluster, manage to improve their economic results. The paper analyses the internationalization process of Bulgarian clusters.
\end{abstract}

Keywords: internationalization, clusters.

Daug mokslinių tyrimų patvirtina, kad klasteriai vaidina svarbų vaidmenị didinant konkurencinę galią, diegiant naujoves ir didinant ekonomikos augimą skirtingose šalyse. Klasterių internacionalizacija yra vienas iš veiksnių, prisidedantis prie klasterių tobulèjimo ateityje. Mažos ir vidutinès ịmonès, veikiančios tarptautiniu lygmeniu kaip klasterio dalis, sugeba gerinti savo ekonominius rezultatus. Straipsnis analizuoja klasterių internacionalizavimo procesą Bulgarijoje.

Raktiniai žodžiai: intenacionalizacija, klasteriai.

\section{Introduction}

Economic theory has established the understanding for the defining role clusters play in increasing competitive power, innovations and economic development. Clusters are a striking feature of all modern economies (Porter, 2009). This inference fully applies to economically developed nations. In many countries around the world, clusters are received positively by governments, businesses and research institutions. Governments in separate countries implement different policies and use a multitude of tools to stimulate the formation of new clusters and the development of existing ones. The European
Union (EU) also focuses its efforts towards more world-class clusters. One of the factors for that is their internationalization.

Clusters in Bulgaria emerge at a later stage compared to the majority of the EU's member states. Currently, there is a large number of clusters in the country over 230 (Association of Business Clusters in Bulgaria, 2013). Despite the large number of clusters in the country, only a handful of them can be classified as developed. This conclusion reinforces the position of multiple experts that the implemented financial tools for supporting cluster development (which are primarily procedures within the EU's operational programme) cause the artificial creation of such structures. 
This article expands research on cluster internationalization by investigating the involvement of Bulgarian clusters in international operations. The research is in response to the practical necessity to create a comprehensive idea about the degree of cluster internationalization in Bulgaria.

The research problem addressed in the article is about finding the level of internationalization of Bulgarian clusters. Correspondingly the research object is the clusters in Bulgaria and the aim of the research is to study the degree of cluster internationalization in Bulgaria.

The research methods. Analytical and comparative methods are used in order to draw conclusions about the degree of cluster internationalization in Bulgaria and the necessary changes in the cluster policy implemented by the Bulgarian state.

The objectives of the article are to analyse the internationalization process of Bulgarian clusters in the two fundamental directions: the clusters participating in the EU's internationalization policy and the clusters that carry out their international activity without European support.

\section{Literature review}

According to some authors, the origin of the cluster theory can be traced all the way back to Alfred Marshall (2013), it develops over the years, becoming a new approach to economic development in the late XX century on the basis of Michael Porter's works. Clusters can be defined as geographical concentrations of interconnected companies and institutions in a particular field (Porter, 1998). While liter- ature provides several definitions of clusters (Rosenfeld, 1997; Feldman, 2005), the concept of clusters consists of several important dimensions.

Clusters are examined as a geographical concentration of specialized firms. They can include suppliers of various machines, equipment, services, and specialized infrastructure. Additionally, they can also include various institutions like universities, trade associations, local authorities, state institutions, non-governmental organizations that would provide specialized training, research-and-development activity, technical and administrative support.

There is significant evidence of the positive impact of clusters on entrepreneurship (Delgado, 2010). There may well be substantial advantages for the new entrepreneur in setting up in an established cluster, and concomitant disadvantages in not locating in such environment (Kuah, 2002). New suppliers have a solid basis for development due to the highly concentrated customer base from multiple enterprises located in a region Clusters also create prerequisites for the development of new businesses due to the presence of multiple trained staff members who are familiar with the specifics of developed industries.

Clusters emerge spontaneously based on market forces (Porter, 2009). The process of cluster formation and development follows its natural course as a result of the formation of new firms, the development of suppliers, investments in infrastructure, collection of specialized information and allocation of production capacity by established firms operating in other regions. The significance of clusters presupposes the implementation of a pub- 
lic policy which would provide the necessary rules for developing a productive business, creating mechanisms and initiatives for improving the effectiveness with which individual enterprises function.

Clusters attain more and more significance for the sustainable economic development of the different regions and countries (Ivanov, 2015). In addition to the undeniable economic benefits which they affect to the economic development of separate regions, clusters also provide wider social and ecological benefits (Slavova, Bankova, 2017). Cluster development is observed in all countries, with varying stages of their emergence (Oxford Research, 2008).

The internationalization of companies has become a key concept in the modern economy. In modern days many firms are taking the advantage to go international. The international trade increases in the scope of products and participants, in scale and in pace and allows meeting timely and effectively the needs of significant groups of people (Tanushev, 2015). As a result of internationalization, there is a growth of firms' engagements as exports and imports, foreign direct investment and others. There is a growing number of evidence that cluster structures play an important role in the process of a firm's internationalization (Kowalski, 2014).

The impact of clusters on the internationalization of cluster firms has been the subject of some empirical studies - (Carneiro Zen at al., 2011; Richardson et al., 2012). Traditionally, clusters are perceived as a phenomenon characteristic of local markets. In modern days clusters no longer limit themselves to regional or national markets. They are increasingly going international. Clusters are a characteristic phenomenon in local or regional markets, but their function is to build a competitive advantage for cluster members on a larger scale - not only national but international (Jankowska, Główka 2016). Clusters are not capable of long-term excellence and development unless their members are acting in global markets and involved in international knowledge transfer (Islankina, 2015). As a result of the globalization process of the world economy (Nayef, 2006) and the specialization in the value chain across national borders (Donchev, 2013), clusters are embracing international strategies and are forming transnational strategic cluster partnerships.

\section{Methodology}

The research is conducted on the basis of studying the web pages of Bulgarian clusters, press interviews, articles, announcements for events in which the clusters participate, etc. The necessary conclusions are drawn from the use of analytical and comparative methods. According to data from the Association of Business Clusters (2013), over 230 clusters function in Bulgaria, with only 82 having web pages. Of those 82,67 have undergone the process of cluster accreditation conducted by the Executive Agency for Small and Medium Enterprises in 2017. The clusters are divided into three categories: early stages of development, developing and developed. In accordance with the Methodology for Categorizing Clusters (2017), in order to receive accreditation, clusters should fulfil six admissibility criteria regarding their legal form, the number of judicial people, etc. The candidates which successfully pass the admissibility test are evaluated 
by six basic criteria: cooperation between cluster members - 17 points; structure, stability, and cluster members - 39 points; strategic planning -7 points; results of the cluster's member firms - 20 points; research-and-development activity of the cluster -8 points; interview with cluster representatives/members - 9 points (includes sub-criteria regarding cluster coordination and cluster structure analysis).

Depending on the obtained number of points, the candidates are divided into one of the following three categories:

- Clusters in early stages of development - over 20 points, and they include a minimum of seven judicial people and/or sole traders. 42 clusters are placed in this category;

- Developing clusters - over 40 points, and they include a minimum of ten judicial people and/or sole traders plus at least one institute of higher education or research-and-development organizations. 21 clusters are placed in this category;

- Developed clusters - over 70 points, and they include a minimum of fifteen judicial people and/or sole traders plus at least one institute of higher education or research-and-development organizations. 4 clusters are placed in this category.

Regardless of the wide range of clusters that have been studied, the substantial informational narrowness should be taken into account. As was indicated earlier, the clusters' web pages have been accepted as the primary source of information about them. In a number of cases, however, there is a situation where there are missing web pages even for clusters which have received accreditation. In some cases, even if a given cluster's web page is avail- able, there is a limitation regarding the small amount of available information. At the stage of providing information, in addition to cluster sites, other sources of information have also been used such as press interviews, articles, announcements for events in which clusters participate, etc. Data from the EU's Uniform Information Portal for Structural Funds has been used and information from the European Cluster Collaboration Platform has also been used and analysed. The platform's focus is encouraging European clusters to work jointly for obtaining a synergic effect and for developing a joint internationalization strategy with common goals aimed at specific third markets. A study was conducted for the fifteen international cluster projects financed within the public announcements to support the establishment of European Strategic Cluster Partnership - Going International (ESCP-4i) and support the initial implementation, testing and further development of European Strategic Cluster Partnerships - Going International (ESCP-4i). Moreover, nine additional voluntary partnerships which accept working on the agenda for cooperation without direct financing by the EU have been studied as well.

\section{Internationalization of Bulgarian clusters}

The exceptionally large number of newly emerged clusters, which considerably exceeds the one in a number of developed countries with experience in cluster development, can be indicated as a result of the implemented national policy for financial support of clusters in Bulgaria. In spite of the implemented policy and 
the initiatives the EU has realized for the development of more clusters on a global level, the number of developed clusters in Bulgaria is still limited.

One of the factors that contribute to the future development of clusters is their internationalization. According to a study on the topic of Internationalization of European SMEs (2010), there is a strong connection between small and medium enterprises that operate on an international level and their better (compared to the EU average) business indicators. The study shows that SMEs operating on an international level show a larger growth in enterprise turnover and number of employees.

At present, however, the main portion of Bulgarian clusters carry out their activity solely within the country. Only seven Bulgarian clusters take active part in internationalization initiatives initiated on an EU level, and the international activity of the remaining Bulgarian clusters is limited.

\section{Analysis of Bulgarian clusters participating in the EU's internationalization policy}

Clusters have become an inseparable element of the EU's policy. There are a number of direct, financial EU tools for supporting cluster development within the implemented policy for internationalization of European business. Based on data provided by the European Commission for the following years, about $90 \%$ of the global growth is expected to be generated outside of the EU. Moreover, developing and newly emerging markets are expected to form $60 \%$ of the global GDP, which ne- cessitates the use of all resources to protect economic interests and aid the prosperity of EU enterprises in the global context.

The growing internationalization of small and medium enterprises, as well as aiding European businesses' access to third markets, is key to European competitiveness, economic growth, and innovations. At present, the European Commission's top priority is to create the appropriate environment for stimulating enterprises to fully benefit from the growth of markets outside the EU.

The internationalization of European business has a positive effect not just on individual enterprises but on national economies and the European economy as a whole, which also necessitates the implementation of a number of tools aimed at stimulating the internationalization of European business.

The EU has initiated 24 European strategic cluster partnerships within its cluster internationalization policy. Seven clusters from Bulgaria take part in three of the said partnerships:

- Automotive Cluster Bulgaria, България - GIVE;

- Cluster Information and Communication Technologies Plovdiv - GIVE;

- Foundation "Cluster Information and Communication Technologies"-GIVE;

- Green Transport Cluster - MOVE;

- Bulgarian Cluster "Telecommunications" - MOVE;

- Electric Vehicles Industrial Cluster MOVE;

- Green Synergy Cluster - NATUREEF.

Within these three partnerships, the Bulgarian clusters partner with 21 clusters which originate from 11 EU member states (Germany, Greece, Denmark, Spain, Italy, Poland, Portugal, Romania, 
Hungary, France, the Czech Republic) and from three countries which are not EU member states (Albania, North Macedonia, Serbia).

The Bulgarian clusters which are members of the European Cluster Collaboration Platform actively participate in the EU's implemented policy for internationalization of their activity. 129 clusters from $20 \mathrm{EU}$ member states participate within the platform. France takes first place with the most clusters -22 , followed by Spain - 21, Germany - 16, Italy - 9, Belgium - 8. Bulgaria takes sixth place along this indicator with 7 clusters, surpassing socio-economically developed countries like the Netherlands, the United Kingdom, Austria, Denmark, Sweden, etc.

The markets that Bulgarian clusters target are eleven countries from four different continents (Azerbaijan, Brazil, Israel, India, Iraq, Kazakhstan, Morocco, Mexico, UAE, USA, the Philippines), as well as four countries from Europe which are not EU members (Albania, Norway, Serbia, Ukraine). What is interesting is that the international activity of two of the Bulgarian clusters - Automotive Cluster Bulgaria and Electric Vehicles Industrial Cluster - is solely aimed at EU countries.

The dimensional structure of Bulgarian clusters is not unlike the structure of the remaining clusters which participate in various European cluster partnerships. A typical trait of all European cluster partnerships is the dominant relative share of small and medium enterprises, whereas large enterprises, research organizations, universities, technological centres, and other participants have a significantly smaller relative share. Similar conclusions can also be drawn when studying the cluster partnerships which Bulgarian clusters participate in. The relative share of SMEs within GIVE is $82 \%, 79 \%$ in MOVE and $74 \%$ in NATUREEF.

Of the Bulgarian clusters participating in the European Cluster Collaboration

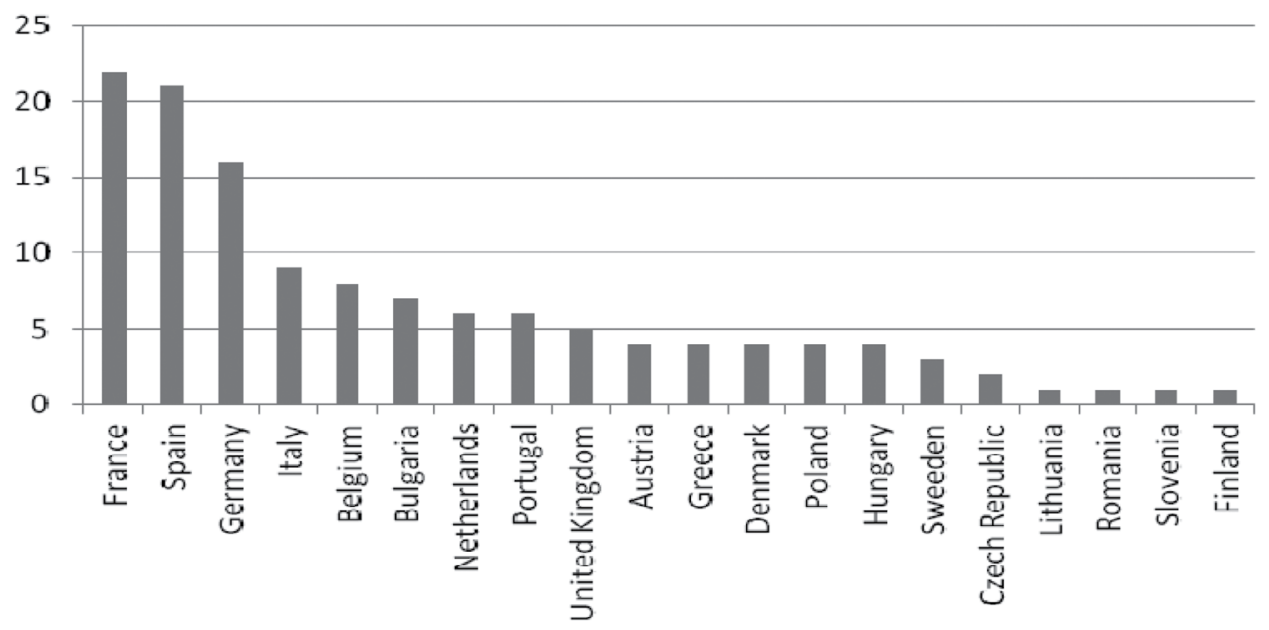

Fig. 1. Number of clusters from EU countries which are members of the European Cluster Collaboration Platform 
Table 1. International activity of Bulgarian clusters which participate in the European Cluster Collaboration Platform

\begin{tabular}{|c|c|c|}
\hline Cluster & $\begin{array}{c}\text { European Strategic Cluster } \\
\text { Partnership }\end{array}$ & Target Countries \\
\hline Automotive Cluster Bulgaria & GIVE & $\begin{array}{c}\text { Croatia, Czech Republic, Germany, } \\
\text { Hungary, Slovakia }\end{array}$ \\
\hline $\begin{array}{c}\text { Cluster Information and } \\
\text { Communication Technologies } \\
\text { Plovdiv }\end{array}$ & GIVE & $\begin{array}{c}\text { Azerbaijan, India, Israel, USA, } \\
\text { Belgium, Germany, Norway, } \\
\text { Poland, Ukraine }\end{array}$ \\
\hline $\begin{array}{l}\text { Foundation Cluster Information } \\
\text { and Communication Technologies }\end{array}$ & GIVE & $\begin{array}{l}\text { United Arab Emirates, Albania, } \\
\text { Greece, Hungary, Romania, Serbia }\end{array}$ \\
\hline $\begin{array}{l}\text { Bulgarian Cluster } \\
\text { Telecommunications }\end{array}$ & MOVE & $\begin{array}{l}\text { Azerbaijan, Brazil, Iraq, Morocco, } \\
\text { Belgium, Germany, Serbia }\end{array}$ \\
\hline Electric Vehicles Industrial Cluster & MOVE & $\begin{array}{c}\text { Denmark, France, Greece, Italy, } \\
\text { Poland }\end{array}$ \\
\hline Green Transport Cluster & MOVE & $\begin{array}{l}\text { Brazil, Kazakhstan, USA, France, } \\
\text { Italy, Romania, Spain }\end{array}$ \\
\hline Green Synergy Cluster & NATUREEF & $\begin{array}{c}\text { Mexico, Philippines, Denmark, } \\
\text { Germany, Spain }\end{array}$ \\
\hline
\end{tabular}

Source: European Cluster Collaboration Platform (https://www.clustercollaboration.eu).

Platform the one with the highest relative SME share is Foundation Cluster Information and Communication Technologies - 98\%, followed by Bulgarian Cluster Telecommunications - 95\%, Green Synergy Cluster - 91\%, Green Transport Cluster - 86\%, Electric Vehicles Industrial Cluster - $82 \%$, Cluster Information, and Communication Technologies Plovdiv $-80 \%$ and Automotive Cluster Bulgaria $-73 \%$.

The highest number of research organizations, universities or technological centres is found in Foundation Cluster Information and Communication Technologies and Electric Vehicles Industrial Cluster -6 in each one. It is important to take into account that there are differences between the two clusters. Due to the large number of member SMEs in Foundation Cluster Information and Communication Technologies, the relative share of research organizations, universities, and technological centres is only $2 \%$, whereas that share in Electric Vehicles Industrial Cluster is $8 \%$. On the opposite end of the spectrum are Green Transport Cluster and Bulgarian Cluster Telecommunications, each of which includes only one organization that can be classified as research, university or technological centre within their structures.

In order to encourage innovations and growth and to strengthen the competitiveness of its economy, the EU has highlighted ten newly emerging industries to secure the Community's future growth. Emerging industries can be understood as "the establishment of an entirely new industrial value chain, or the radical reconfiguration of an existing one, driven by a disruptive idea (or convergence of ideas), leading to turning these ideas/opportunities into new products/services with higher added value" (European Commission). 
A report titled "European Cluster Panorama 2014" of the European Cluster Observatory has outlined ten newly emerging industries - defined as such because of their dynamism (measured through the annual growth of employment in the last four years) and/or productivity (measured through the average size of remuneration) within the traditional 51 cluster categories. These industries include:

- Advanced Packaging;

- Biopharmaceuticals;

- Blue Growth Industries;

- Creative Industries;

- Digital Industries;

- Environmental Industries;

- Experience Industries;

- Logistical Services;

- Medical Devices;

- Mobility Technologies.

The seven Bulgarian clusters participating in the European Cluster Collaboration Platform have aimed their activity in 5 of the 10 newly emerging industries: Environmental Industries, Experience Industries, Logistical Services, Mobility Technologies, and Digital Industries.

\section{International activity of the remaining Bulgarian clusters}

The international activity of the remaining Bulgarian clusters (outside of the ones which are members of the European Cluster Collaboration Platform) is limited. It is carried out in several different directions: business partnership with clusters and organizations from other countries, partnership and membership in various international organizations, participation in international conferences, fairs and presentations.
Bulgarian clusters conduct business cooperation primarily with clusters and organizations originating from countries on the Balkan Peninsula. Seven Bulgarian clusters carrying out internationally aimed activities have been identified within the study:

- Cluster Promarket Plus - Varna - orientated towards Argentina and France;

- Cluster Renewable Energy Sources orientated towards the Republic of North Macedonia;

- Cluster Itos - orientated towards the Republic of North Macedonia;

- Specialized Cluster Institute for Apparel and Textile - Dunav - orientated towards the Republic of North Macedonia and Romania;

- Cluster for Education, Training and Qualifications - orientated towards Serbia;

- Cluster for Development of Satellite Communications - orientated towards Serbia;

- Music Media Cluster - within the framework of the cluster Balkanika music television is broadcasted in all countries on the Balkan peninsula Bulgaria, Albania, Bosnia and Herzegovina, Greece, the Republic of North Macedonia, Romania, Slovenia, Serbia, Turkey, Croatia and Montenegro, as well as Germany, USA, and Canada. Bulgarian clusters also carry out international activities in terms of partnership and membership with various organizations:

- Cluster Trakia Economic Zone - partner with the Bulgarian-Chinese Association for Business Development;

- Marine Cluster Bulgaria - member of the European Network for Marine Clusters; 
- Branch Association Polymers - member of PlasticsEurope - European Association of Plastics Manufacturers;

- ICT Cluster Burgas - member of the Balkan and Black Sea Networks of ICT clusters.

In addition to the aforementioned directions, Bulgarian clusters also send their representatives to various international conferences and fairs where they have the opportunity to present their activities. The clusters which carry out this type of activity include: Industrial Cluster Srednogorie, Cooperative Cluster, Cluster Sofia - Knowledge City, Cluster of Cable Operators Sim Net, etc.

\section{Conclusions}

One of the factors that play a role in the future development of clusters as a whole, as well as their member enterprises, is their internationalization. At present, however, only a very small portion of Bulgarian clusters are taking actions to internationalize their activity.

Only seven Bulgarian clusters are members of the European Cluster Collaboration Platform and participate actively in the internationalization initiatives initiated on an EU level. The study ascertains the fact that the dimensional structure of Bulgarian representatives in the platform is not unlike that of other countries participating in various European cluster partnerships. Over $70 \%$ of the members of Bulgarian clusters are small and medium enterprises, whereas large enterprises, research organizations, universities and technological centres have a significantly smaller relative share. The activity of the seven Bulgarian clusters is aimed at five of the ten newly emerging industries, namely: environmental industries, experience industries, logistical services, mobility technologies and digital industries.

The international activity of all other Bulgarian clusters is limited. From the conducted research it can be inferred that the remaining Bulgarian clusters have aimed their efforts primarily at achieving business cooperation with clusters and organizations that originate from countries on the Balkan Peninsula.

The negative conclusions regarding the internationalization of Bulgarian clusters necessitate changes in cluster policy and increasing the effectiveness of financial support by the Bulgarian state. At this stage, the state's current policy leads to the presence of a large number of clusters, but only a handful of them can be categorized as developed. Developed clusters play a defining role in increasing competitiveness, innovations and economic development. It is necessary to redirect efforts at forming developed clusters which, through the process of internationalization, will provide member SMEs with a larger growth in both turnover and number of employees. 


\section{References}

1. Association of Business Clusters in Bulgaria (2013). Pozitsia na Asotsiatsia na Biznes Klasterite $\mathrm{v}$ Bulgaria (ABK). Internet access: http://www.emic-bg.org/news/item/804, 2013, [accessed October 2019].

2. Carneiro Zen, A., Fensterseifer, J. E., Prevost, F. (2011). Internationalization of Clustered Companies and the Influence of Resources: A Case Study on Wine Clusters in Brazil and France Latin American Business Review. Vol. 12 No. 2, pp. 123-141. doi: 10.1080/10978526.2011.592799

3. Delgado, M., Porter, M. E., Sternc, S. (2010). Clusters and Entrepreneurship // Journal of Economic Geography. Vol. 10, Issue 4. doi: 10.1093/jeg/lbq010

4. Directorate-General for Enterprise and Industry, European Commission (2010). Internationalisation of European SMEs - Final report. Internet access: ec.europa.eu/DocsRoom/ documents/10008/attachments/1/translations/ en/renditions/native.

5. Donchev, N. (2013). Integration and Specialization // Business Directions. No. 2/2013.

6. European Cluster Collaboration Platform. Internet access https://www.clustercollaboration. eu [accessed December, 2017].

7. European Commission. Internet access: https:// ec.europa.eu/growth/smes/access-to-markets/ internationalisation_en; https://ec.europa.eu/ growth/industry/policy/cluster/observatory/ cluster-mapping-services/cluster-panorama_en [accessed September 2019].

8. European Structural and Investment Funds Information Portal. Internet access: https://www. eufunds.bg [accessed July 2019].

9. Feldman, M., Francis, J., Bercovitz, J. (2005). Creating a Cluster while Building a Firm: Entrepreneurs and the Formation of Industrial Clusters // Regional Studies. Vol. 39, pp. 129141. doi: 10.1080/0034340052000320888

10. Islankina, E. (2015) Internationalization of Regional Clusters: Theoretical and Empirical Issues - Higher School of Economics Research Paper No. WP BRP 41/STI/2015. doi: 10.2139/ ssrn.2623532

11. Ivanov, I. (2015). Clusters and Security - Chapter of Regional Development // Entrepreneurship and Local Production Systems. Faculty of Economics Matej Bel University in Banská Bystrica, Slovakia. pp. 17-21.
12. Jankowska, B., Główka, C. (2016). Clusters on the Road to Internationalization - Evidence from a CEE Economy // Competitiveness Review. Vol. 26, No. 4, pp. 395-414. doi: 10.1108/ CR-02-2015-0010

13. Kamara na energiynite oditori (2017). Methodology for Categorizing Clusters by Procedure BG16RFOP002-2.009 „Razvitie na klasteri v Bulgaria“. Internet access: https://www. cee.bg/index.php/news-and-events/news/10bg16rfop002-2-009 [accessed July 2019].

14. Ketels, C., Protsiv, S. (2014). European Cluster Panorama - Center for Strategy and Competitiveness, Stockholm School of Economics. European Cluster Observatory Report, Ref. Ares (2014)3462297 - 20/10/2014.

15. Kowalski, A. (2014). The Role of Innovative Clusters in the Process of Internationalization of Firms // Journal of Economics, Business and Management. Vol. 2, No. 3, pp. 181-185. doi: 10.7763/JOEBM.2014.V2.121

16. Kuah, Adrian, T. H. (2002). Cluster Theory and Practice: Advantages for the Small Business Locating in a Vibrant Cluster// Journal of Research in Marketing and Entrepreneurship: Vol. 4, Issue 3, pp. 206-228. doi: 10.1108/14715200280001472

17. Marshall, A. (2013). Principles of Economics. Palgrave Macmillan, First edition 1890.

18. Nayef, R. F. Al-Rodhan, Gérard, S. (2006). Definitions of Globalization: A Comprehensive Overview and a Proposed Definition, Geneva, Geneva Centre for Security Policy.

19. Oxford Research (2008). Cluster Policy in Europe. A Brief Summary of Cluster Policies in 31 European countries. Europe Innova Cluster Mapping Project. Internet access: ttp://www. clusterobservatory.eu/system/modules/com. gridnine.opencms.modules.eco/providers/ getpdf.jsp?uid=100146 [accessed October 2019].

20. Porter, M. E. (2009). Clusters and Economic Policy: Aligning Public Policy with the New Economics of Competition. Institute for Strategy and Competitiveness, October 2009.

21. Porter, M. E. (1998). Clusters and the New Economics of Competition // Harvard Business Review 76, November-December, pp. 77-90.

22. Richardson, C., Yamin, M., Sinkovics, R. R. (2012). Policy-driven Clusters, Interfirm Interactions and Firm Internationalization: Some Insights from Malaysia's Multimedia 
Super Corridor // International Business Review, Vol. 21, No. 5, pp. 794-805. doi: 10.1016/j.ibusrev.2011.09.002

23. Rosenfeld, Stuart A. (1997). Bringing Business Clusters into the Mainstream of Economic Development // European Planning Studies. Vol. 5, Number 1. doi: 10.1080/09654319708720381

24. Slavova, I., Bankova, Y. (2017). The Role of Clusters for Sustainable Development: Socially Responsible Practices, Limitations and Challenges. Case Study of a Bulgarian Industrial Cluster - 34th International Academic Conference, Florence, 13 September
2017, ISBN, IISES, pp. 199-225. doi: 10.20472/ IAC.2017.034.051

25. Tanushev, C. (2016) Globalization or New National Borders // International Scientific Business Conference Government, Enterprise, Entrepreneur, Belgrade, Serbia, 2016, Proceedings, pp. 380-392.

The paper submitted: August 10, 2019

Prepared for publication: December 10, 2019

\section{Christo IVANOV}

\section{KLASTERIỤ INTERNACIONALIZACIJA BULGARIJOJE}

\section{$\mathrm{S}$ a n t r a u k a}

Daug mokslinių tyrimų patvirtina, kad klasteriai vaidina svarbų vaidmenį didinant konkurencinę galią, diegiant naujoves ir skatinant ekonomikos augimą skirtingose šalyse. Daugelyje pasaulio šalių vyriausybès, įmonès ir mokslinių tyrimų institucijos pozityviai vertina klasterius. Klasterių internacionalizacija yra vienas iš veiksnių, prisidedančių prie šalių raidos. Mažos ir vidutinès įmonès, veikiančios tarptautiniu lygmeniu kaip klasterio dalis, sugeba gerinti savo ekonominius rezultatus.

Šio mokslinio tyrimo tikslas yra išanalizuoti klasterių internacionalizavimo laipsnị Bulgarijoje. Norint tai pasiekti, analizuojama informacija apie faktiškai veikiančius šalies klasterius. Internacionalizavimo procesas buvo nagrinejamas dvejomis pagrindinemis kryptimis. Pirmiausia analizuojami ES internacionalizavimo politikoje dalyvaujantys klasteriai, po to pristatomi tarptautinę veiklą be Europos Sąjungos paramos vykdantys klasteriai.

Pagrindinè tyrimo išvada yra ta, kad šiuo metu labai nedidelè dalis Bulgarijos klasterių imasi veiks- mų internacionalizuoti savo veiklą. Nepaisant didelio klasterių skaičiaus Bulgarijoje, tik septyni iš jų yra Europos klasterių bendradarbiavimo platformos (angl. European Cluster Collaboration Platform) nariai, aktyviai dalyvaujantys ES lygmeniu inicijuotose internacionalizavimo iniciatyvose. Visų kitų Bulgarijos klasterių tarptautinè veikla yra gana ribota. Iš atliktų tyrimų galima daryti išvadą, kad ES iniciatyvose nedalyvaujantys klasteriai savo pastangas siekia pirmiausia nukreipti ị bendradarbiavimą su verslo klasteriais ir organizacijomis, kilusiomis iš Balkanų pusiasalio šalių.

Straipsnio autorius daro išvadą, kad norint skatinti Bulgarijos klasterių internacionalizavimą būtina pakeisti klasterių politiką ir efektyviau naudoti Bulgarijos vyriausybès jiems skiriamą finansinę paramą. Būtina labiau koncentruoti pastangas ị išsivysčiusių klasterių formavimą, kurie per internacionalizavimo procesą padès mažoms ir vidutinèms imonèms sparčiau didinti tiek savo apyvartas, tiek ir darbuotojų skaičių. 